\title{
ON BELATEDNESS. THE SHAPING OF PORTUGUESE ART HISTORY IN MODERN TIMES *
}

\section{INTRODUCTION}

Portuguese history of art had its own twentieth-century master narrative, a simulacrum of the modernist master narrative that has been widely criticised but not entirely put aside. Heir to the nineteenth-century compulsion for mapping and archiving national history, in its early days the history of art in Portugal was part of that broader field of knowledge comprising archaeology, anthropology, ethnology and, of course, history. That compulsion persisted, but it was modernised with an approach that became institutional art history practice and was motivated by the will to innovate and develop both art practice and art history (and criticism) in order to match foreign proposals regarded as models.

This article will briefly trace the genealogy of art history writing in Portugal until the significant development that Portuguese history of art experienced after World War II, especially with the work of José-Augusto França (b. 1922), who was responsible for establishing a historiographic canon for nineteenth- and twentieth-century Portuguese art and was also the founder of the academic discipline of art history in Portugal. I propose to analyse the concept of belatedness that is found in his writings, tracing its background, and to demonstrate how it has been associated with the concept of civilisation. Both performed a structural role in Portugal's cultural history. Putting the Portuguese case in context will help to see how much of the narrative on

* This article was written in the context of the project Iberian modernisms and the primitivist imaginary (PTDC/ART-HIS/29837/2017) - co-financed by COMPETE 2020, Portugal 2020 and European Union (European Fund for Regional Development). 
modernism is itself modernist and how it has depended on a structurally imperial way of thinking, which has rivalry and hierarchy as its main features to elect or neglect artistic practices.

\section{SOME EPISODES OF PORTUGUESE HISTORY OF ART FROM THE NINETEENTH AND EARLY TWENTIETH CENTURIES}

There are some works that are usually considered amongst the first histories of art produced in Portugal. Although there is no consensus on this, the work written by the painter Cyrillo Volkmar Machado (in particular his Collecçao de Memorias (1823)|1 is the one I shall mention first. He was indicated as being the first to depart from the vasarian model, ${ }^{2}$ writing in an empiricist and analytical way, using chronologies to establish analogies and differences, being "obsessed with facts" ${ }^{3}$ and having "a historical consciousness." ${ }^{4}$ Cyrillo

1 The full title was Colecção de memorias relativas às vidas dos pintores, e escultores, architetos, e gravadores portuguezes, e dos estrangeiros que estiverão em Portugal which can be translated by: "Collection of memories related to the lives of painters and sculptors, architects and printmakers both Portuguese and foreigners that have been to Portugal." Cyrillo Volkmar Machado lived between 1748 and 1823 and wrote other works related with painting and architecture, combining pedagogy, aesthetics and history. In the sixteenth century, there was an interest in archaeology in such Renaissance authors as Damião de Góis and André de Resende. Also, Leon Battista Alberti was translated by that time. The important work by Francisco de Hollanda (1517-1585) was only known much later in the late nineteenth century, and it was fully published only in the 1960s. Between 1580 and 1640, Portugal was ruled by Spain and during that period publications on national themes were scarce. Only afterwards were new works published, mostly following the Vasarian model. See A.M. Gonçalves, "Historiografia de Arte em Portugal," Boletim da Biblioteca da Universidade de Coimbra 1960, 25.

2 This was noted by Paulo Varela Gomes in 1988. Cf. "Cyrillo Volkmar Machado e a História da Arte em Portugal na transição do século XVIII para o século XIX," in: idem, A Cultura Arquitectónica e Artística em Portugal no século XVIII, Lisbon 1988, pp. 149-73, and later by Foteini Vlachou, "The absence of Vasari: The reception of the Vite in Portugal c. 1568-1823," in: Vasari als Paradigma. Rezeption, Kritik, Perspektiven / The Paradigm of Vasari. Reception, Criticism, Perspectives, eds. F. Jonietz, A. Nova, Conference Proceedings, Marsilio, Florence, Kunsthistorisches Institut, Max-Planck-Institut, 2014, pp. 275-284 (Included in F. Vlachou, The Disappointed Writer. Selected Essays, Lisboa 2019, pp. 31-57). Both authors also note that Cyrillo quotes Winckelmann frequently, but has no problem in often disagreeing with him, for instance, by praising Bernini.

3 Gomes, "Cyrillo Volkmar Machado...," p. 155.

${ }^{4}$ In Cyrillo's writings, Paulo Varela Gomes identifies the consciousness of time continuities and an expectation of the future, ibidem, p. 150. 
Volkmar Machado explained artistic facts and developments, not by establishing closed cycles of rising and decadence, but by searching for causal facts outside the artistic field. In spite of its limitations, his work was regarded by the art historian Paulo Varela Gomes as the first to propose a periodisation of Portuguese art and his method of finding connections between artistic and non-artistic facts was indeed an approach that instead of trying to find art objects, produced them, as a result of the intertwining of facts in a historical narrative. ${ }^{5}$ Cyrillo held Portuguese art in low regard, and he shared the view that a general decadence was installed in all art, but he attributed this to external facts, not artistic facts.

There were some authors from Romanticism that gathered efforts to document the nation's art and monuments, namely two of the most famous intellectuals, the writer Almeida Garrett (1799-1854) and the historian Alexandre Herculano (1810-1877), who wrote, respectively, an essay on history of painting and a study about national monuments, as well as other about Gothic architecture. ${ }^{6}$ Herculano would also write several novels about monuments and other national works of art and in 1846 he started to publish his History of Portugal in several volumes.

However, José-Augusto França, the author of the master narrative of nineteenth- and twentieth-century Portuguese art, considered that the true history of art in Portugal only started later, with a foreigner, Count Atanazy Raczyński (1788-1874). França approved of the fact that this Polish aristocrat, a minister in the Portuguese Court in 1842-1845, was a correspondent of the Berlin Artistic and Scientific Society, to which he sent his studies on Portuguese art. França goes on to say that Raczyński, as "a man of knowledge and taste," did "the first modern work of history criticism" and that he "dropped into the Portuguese milleu like a bomb, publishing neglected documents and showing the mistakes, insufficiencies and pretensions of previous researchers, artists and collectors." ${ }^{\prime 7}$ In short, his highest merit was to have been trained abroad and exposed Portuguese belatedness. This was, states França, the most evident case of someone who had the training to apply a state-of-the-art nineteenth-century methodology - "a classic taste tempered by a high German idealism, romantic but with a Roman gravity," ${ }^{\prime \prime}$ focused on identifying correct authorship and dismissing "bad taste" eclecticism such as the Pena Palace

5 Ibidem, p. 172.

6 A. Garrett, Ensaio sobre História da Pintura, 1821, and A. Herculano, Monumentos Pátrios, 1838; "A Arquitectura Gótica," Panorama 1837, 1. See Gonçalves, "Historiografia de Arte em Portugal."

7 J.-A. França, A Arte em Portugal no Século XIX, Lisbon 1990 [1967], pp. 392-393.

8 Ibidem, p. 395. 
in Sintra ${ }^{9}$ - this enabled him to express paternalism, hoping that Portugal would progress in the arts, but diagnosing that for the time being, everything was yet to be done. França enhances his education and the "lesson of quality" he brought to the country, lamenting the national artistic ignorance that preferred to be offended rather than learning with him. The art historian praises another foreigner, the Briton Sir John Charles Robinson (1824-1913), who was responsible for the South Kensington Museum (currently the Victoria \& Albert) and who published some articles on Portuguese painting in Britain, "and gave the country another example of professional work." 10

França recognises the privilege that these men had in their education and in the institutions they came from, but he tends nevertheless to diminish Portuguese artistic and intellectual capacities, often classifying them as ignorance, lack of intelligence or "Portuguese mentality" the putative incapacity of doing the same as what central European scholars and artists could do. França constantly underlines Portugal's subaltern status, never equating the possible inadequacy of the foreigners' approach to Portuguese reality. For him, history would have had to have been different to match their methodologies and the objects and narratives they were searching for. It was not social, cultural, economic or political reasons that had determined the Portuguese context, but an inherent lack of will to do things the "right" way.

The art historian Nuno Rosmaninho has traced a genealogy for Portuguese art history, identifying a methodology with a "scientific influx" that starts in the first half of the nineteenth century. ${ }^{11} \mathrm{He}$ also considers Raczyn-

9 Palácio da Pena in Sintra was built between 1842 and 1854 on the ruins of a monastery and it was a personal project of the consort Ferdinand II, husband to Queen Maria II of Portugal. It combines several revivalisms.

10 França, A Arte em Portugal no Século XIX, p. 396.

${ }^{11}$ Nuno Rosmaninho prefers to name this approach "methodic" or with a "scientific influx" and not "positivist" because of lack of direct reference to Auguste Comte. Comte's positivism did not consider the gathering of facts a condition for the practice of science. N. Rosmaninho, "Estratégia e Metodologia na Historiografia Artística Portuguesa (18461935)," Revista da Universidade de Aveiro. Letras 1997, 14, p. 86. I nevertheless use the term "positivism" to refer to Portuguese art history, for the matrix of its practice is nineteenth-century positivism in a larger sense, which includes Leopold von Ranke's empiricism. Although Ranke claimed the necessity for understanding and explaining facts, he was nevertheless championed as positivist due to his stances regarding history's autonomy and independence towards philosophy, and due to seeing history as a scientific endeavour. He defended that history should focus on the individual and should follow an inductive methodology rather than deductive, which ultimately means a rejection of philosophy of history or, in other terms, a rejection of theory. See F. Beiser, The German Historicist Tradition, Oxford University Press, 2011, pp. 254-261. (F. Beiser distinguishes Ranke from 
ski to be the first Portuguese art historian in whom he sees for the first time a rigorously trained method. The positivist matrix lasted throughout the twentieth century and co-existed with the vasarian-like biography (practised in the Dictionaries of Artists - one of the most enduring ways of writing the history of art), often in an exhaustive compilation of biographical facts with no attention to social context. Another practice was the "Memória Histórica e Descritiva" [Historical and Descriptive Memory], which applied the same exhaustiveness to the description of buildings, and the historical events that were related to them, mostly in a formalist approach, and exclusively to architecture. ${ }^{12}$ Rosmaninho also refers to what he calls a problematising way of practising art history, that is, the identification of problems and themes and argumentation and positioning concerning those problems and themes. There were mainly two currents within this practice; one was nationalistic and tried to establish a national artistic specificity ${ }^{13}$ and discussed national styles like manuelino. ${ }^{14}$ The other distanced itself from patriotic views, rejected any idea of Portuguese superiority and identified a constant dependence on foreign models in Portuguese art. This was shared, for instance, by Joaquim de Vasconcelos (1849-1936) and Virgílio Correia (1888-1944), two

Comte's positivism but does not oppose them, seeing common ground between both as well as some differences, such as Ranke's idea that history could be both scientific and artistic). Positivism in a larger sense refers to the conviction that the past can be told exactly how it happened and that a massive fact accumulation based on primary sources is enough as scientific research and interpretation can be left aside (a belief that can still be found in the Portuguese Academy). It is also part of what was called historicism, a complex term which has been related to different and even contradictory practices, but that was mainly associated with the German History School, characterized by the belief in "objective" historical knowledge and the idea of history as progress. See P. Osborne, "Historicism as bad modernity," in: The Politics of Time: Modernity and the Avant-Garde, London 1995, p. 138.

12 Rosmaninho, "Estratégia e Metodologia...," pp. 71-92. In the beginning of the twentieth century, art history publications of this sort were enriched by photography, which actually became more relevant than the text. Photography was claimed as a relevant (art) history instrument by Ramalho Ortigão, Sousa Viterbo and Joaquim de Vasconcelos, all authors that were simultaneously art historians, historians, writers, ethnographers or archaeologists, etc. with no necessary distinction between those practices. Ibidem, p. 81 .

13 This was the position of, for example, Ramalho Ortigão, 1836-1915, or José de Figueiredo, 1872-1937. See Rosmaninho, "Estratégia e Metodologia...," p. 82.

${ }^{14}$ Manuelino refers to the architectural and sculptural late Gothic programme promoted in the reign of D. Manuel I (1495-1521), and related with its affirmative expansionist politics. The term was coined by Francisco Adolfo Varnhagen, a Brazilian with a German father, in 1842 in a study about the Belém Tower in Lisbon, Notícia Histórica e Descriptiva do osteiro de Belém. 
scholars with a strong and consistent methodology. Following Rosmaninho, Vasconcelos was the first and only one to place art within an economic perspective, and Correia the first to establish a dichotomy centre/periphery. ${ }^{15}$ The two currents prevailed throughout the twentieth century, and although apparently at variance, they share the same kind of approach. In general, from the twentieth century on, the history of art in Portugal pursued scientific legitimation aimed at objectivity by intense description and fact accumulation, as well as having few doubts (with the exception of Joaquim de Vasconcelos, who carefully appeals to verification and critical sense). This coexisted with an idealist conception of art and the fact accumulation eventually justified historiographic options and positions based on personal taste and judgement.

\section{THE ESTRANGEIRADO EFFECT}

França's position may be traced back to that of the estrangeirados, a term coined to refer to those that, since the eighteenth-century, had had a foreign education or an interest in what was foreign ("estrangeiro" means "foreign" in Portuguese). ${ }^{16}$

The term had either a negative connotation, raising the suspicion of lack of patriotism, or a positive reading, meaning that those who were estrangeirados were open-minded and looked upon foreign models to promote developing their own country. The scientific revolution of the eighteenth century made its way to Portugal thanks to the role of the estrangeirados network. ${ }^{17}$ Their task often had a component of ferocious criticism of the way things were administrated, cultivated and organized in Portugal. In the twentieth century, the term was used by the essayist António Sérgio (1883-1969), ${ }^{18}$ who

15 Rosmaninho, "Estratégia e Metodologia..."

16 In 1971, the philosopher Eduardo Lourenço (b. 1923) noted exactly this: "Is José-Augusto França's critical approach the last metamorphosis of the famous estrangeirado criticism, more able to detect what lacks (following an imaginary model situated somewhere else) than what we are?" E. Lourenço, "Os Círculos dos Delaunay ou o Estatuto da nossa Pintura," in: idem, O Espelho Imaginário. Pintura, Anti-Pintura, Não-Pintura, Lisboa 1996 [1971], pp. 115-116.

${ }_{17}$ See A. Carneiro, A. Simões and M. P. Diogo, "Enlightenment Science in Portugal: The Estrangeirados and Their Communication Networks," Social Studies of Science 2000, 30(4), pp. 591-619.

18 António Sérgio was a philosopher, historian, educationist, politician and essayist. He was the minister of Education for a brief period in 1923, creating scholarships for studying abroad and financing research and the modernization of schools. He was one of the 
recalled the role of the estrangeirados in Portugal to reinforce a profound national self-criticism. José-Augusto França met António Sérgio, of whom he would later recall: "he taught me how to think." 19

In 1926, the year of the military coup that installed a dictatorship ${ }^{20}$ and just before leaving the country to travel to Paris, where he stayed until 1933, Sérgio wrote an essay called "O Reino cadaveroso ou o problema da cultura em Portugal" [The Cadaveric Reign or the Culture Problem in Portugal].

Those who made the criticism, António Sérgio and the authors to whom he considered himself heir, did so from a superior point a view, an illuminated one, for they believed they had the necessary knowledge to propose, create and implement the reformations needed to surpass the belatedness, but they generally and persistently felt themselves outnumbered by the reactionary forces.

In his essay, Sérgio traces back to the sixteenth century the moment when Portugal was perfectly aligned with the "best European spirit," that is, the "mentality of the cultivated people." 21 That was the time of the so-called "discoveries," the conquest of territories unknown to Europe or that had remained unexplored in Africa, South America (Brazil) and India, as well as the economic enterprises to China and Japan. It was the making of an empire, with territorial conquest and an organized economic network that would control the major trade routes, and would last several centuries, although it would be exceeded in size and power by other well-known European empires from the late sixteenth century onwards. For Sérgio, Portugal was the European avant-garde in the 1500s, but had since lost its status and became a permanently backward nation. One of the eighteenth-century's estrangeirados had

directors of an important magazine, Seara Nova, which played a crucial role opposing to the Portuguese fascist regime.

19 J.-A. França, interviewed by J. C. Saraiva, Sol, Lisbon, May 2016.

${ }^{20}$ After 1933 and the rise of António de Oliveira Salazar to power, this dictatorship adopted fascist characteristics, for instance, the salutation by raising the right hand, or by establishing obligatory "civil education" for young boys and girls (separately) regarding national values and to teach them their roles as citizens of the regime (Mocidade Portuguesa). Censorship, control of arts and culture, political imprisonments and torture were also installed, as well as a network of informers of potential subversive behaviour. The historian Fernando Rosas has recently analysed the common ground between the Portuguese and other European dictatorships, emphasizing its fascist characteristics. F. Rosas, Salazar e os fascismos, Lisbon 2019.

${ }^{21}$ A. Sérgio, "O reino cadaveroso ou o problema da cultura em Portugal," in: idem, Ensaios II, Lisboa 1972 ( $2^{\text {nd }}$ edition); the essay was written in 1926 and read in that same year at a conference in Coimbra. 
already called Portugal the "Cadaveric Reign" or "the Reign of Stupidity,"22 and Sérgio recovers this terminology to apply it to his own epoch. ${ }^{23}$ The nostalgia for sixteenth-century Portugal that António Sérgio expresses is directly connected with the "discoveries": the development of mathematics, geography, the questioning of the medieval authorities were all due, according to him, to the needs and consequences of sea travel. Sérgio praises travelling for providing experience, open-mindedness and a critical attitude, while neglecting every other consequence of the politics of conquest, land occupation and people subjugation. For him "discovery" stands for an inquiring and investigatory spirit.

What happened in the seventeenth century then? For Sérgio, the country took a backwards turn with the "fires of the inquisition" and the persecution of foreigners. At that moment, the Portuguese started to be seen, and righteously so, according to Sérgio, as the "Indians of Europe" or "cafres" [kaffir]. ${ }^{24}$ It is worth noting that the terms used for self-deprecating reference the people of the "discovered" lands - the Indians in Brazil or the African people, here designated by an extremely derogatory name. Therefore, being belated was like being a different kind of foreigner, an Indian or an African. For António Sérgio, the only foreigners to look up to are within Europe, and Portugal, a European country was meant to live up to continental prestige.

The ones who became estrangeirados were those who escaped the inquisition, intellectual Jews, and also those who studied abroad or who established themselves in other countries for political reasons, and finally, later some of the Jesuits persecuted by the Marquis de Pombal (himself inspired by England, where he had been ambassador) in the eighteenth century. They would harshly criticize Portuguese culture and the lack of development, a criticism that continued in the nineteenth century. This was first done by the so-called Romantic generation of Almeida Garrett and Alexandre Herculano, who had

22 Ribeiro Sanches (1699-1783), a Portuguese physician and philosopher, who studied in London and became a physician for the Russian court, but was later exiled in Paris for being Jew. Apud, ibidem, p. 28.

${ }_{23}$ The poet, writer, critic and teacher Jorge de Sena (1919-1978) acquired Brazilian citizenship in 1963 and was a Portuguese Literature teacher at Wisconsin University in the USA. Himself a estrangeirado, he would later also call a two-volume set of essays O Reino da Estupidez [The Reign of Stupidity, 1961].

24 "No século de Descartes e Espinosa éramos uns índios tupinambás" [In Descartes' and Espinoza's century we were like tupinambá indians], Sérgio, "O reino cadaveroso ou o problema...," p. 42. At the beginning of his essay, he quotes António Vieira, writing: "O nome, que não sem razão nos chamam, de cafres da Europa..." [The name which we are called, not without reason, is the kaffirs of Europe], p. 26. 
both spent time in exile in England while participating in the revolt against absolute monarchy (1831) (the absolutists would later be defeated in 1834 by the liberal victory in the Portuguese Civil War). The second group of critics was the so-called Generation of the 1870s, composed of writers and poets who advocated for realism and naturalism, and had strong, albeit not necessarily coincident, political convictions. Their famous "Casino" lectures ended up being forbidden by the Government. It is mostly from one of these authors, Antero de Quental (1842-1891), that António Sérgio derives his own national diagnostic. ${ }^{25}$

\section{DECADENCE OR BELATEDNESS}

In 1871 Quental, who promoted socialist and anarchist ideas, gave one of the most famous Casino lectures, titled "Causas da decadęncia dos povos peninsulares" [Causes of the Decadence of the Peninsular People], where he referred to Spain and Portugal as convergent in their years of glory and their years of decadence, although without advocating a joint peninsular nation. ${ }^{26}$ In fact, he would consider the decline to have started after a crisis caused by the death of the only male heir to the throne, D. Sebastião, in 1580, which resulted in Portugal being ruled by the Spanish monarchs until 1640. In this, as in the rest of his lecture, one can notice that Sérgio repeats almost exactly Quental's words: Portugal was once great and the "peninsular race" was naturally "intelligent" with "independent," "original" and "inventive" "genius.". The Portuguese and Spanish were "naturally democratic" and a "noble people" in which nobleman and common people had lived in harmony. This mythical national essence is taken as the reason for the rise of a "brilliant world, created by the peninsular genius in its free expansion" 28 and corresponds chronologically with the expansion and conquest of the "discoveries" in the fifteenth and sixteenth centuries (Quental starts the era of glory slightly earlier than Sergio), and with the influence of Neoplatonic philosophy with its consequences in the development of universities, science, literature and the arts. The causes of decadence after that golden era reside in the loss of three civilising factors:

${ }^{25}$ Joaquim Pedro de Oliveira Martins (1845-1894), historian and politician, was also a reference for António Sérgio, as well as the writers Eça de Queiroz (1845-1900) and Ramalho Ortigão (1836-1915), all figures of the 1870s Generation.

26 A. de Quental, Causas da Decadencia dos Povos Peninsulares [1871], Lisbon [no date].

27 Ibidem, p. $14 \mathrm{ff}$.

${ }^{28}$ Ibidem, p. 20. 
moral freedom, a rising middle class and the development of industry. The main factor for this loss of civilisation was, says Quental, Catholicism after Trento, with the rule of the Inquisition and the Jesuit domination of the colonies. According to Quental, what united Spain and Portugal in their misery for three centuries was their subjugation to the Catholic Church. ${ }^{29}$

There are two points I would like to emphasize in Quental's lecture. One is that decadence is associated with the rise of absolutism (absolute Church and absolute monarchy), or, generally, with authoritarianism and the restraint of freedom. The second is that decadence is associated with a lack of civilisation. They are, in fact, interconnected, since for him, civilisation is equivalent to the progressive path to a socialist society, with strong industry to provide work to a strong proletarian class. ${ }^{30}$

To recover its legitimate place in civilisation, the country should put the aristocratic values behind, to embrace modern industry and democracy and to free itself from foreign dependence. This does not mean, however, a rejection of the foreign per se. Quental criticizes the expelling of foreigners and Jews by the Inquisition ${ }^{31}$ and he regards British colonization and industry as a role model. The issue in question was national economic autonomy - an autonomy as good and as civilised as the ones seen in Britain and other foreign countries. As for the colonies, Quental bemoans the fact that the Portuguese colonization was not better executed, not the colonization in itself. He vigorously condemns the religious missions, slavery and slaughter for this failure,

29 As Onésimo Teotónio Almeida has pointed out, a similar diagnosis was made by Spanish authors such as Adolfo de Castro's Examen Filosofico sobre las principales causas de la decadencia de Espańa (1852). See O. T. Almeida, "Antero de Quental on the Causes of the Decline of the Iberian Peoples: A Revisitation," Mediterranean Studies 1989, 1, pp. 134-136. This essay analyses Quental's lecture examining the causes he determines for the Iberian decline, and partly disagreeing with them. However, it does not question the diagnosis of belatedness, nor does it question the European hierarchy in which that diagnosis is based.

30 "Against the industrial inertia, let us oppose the initiative of free work, the industry of the people, by the people and for the people ... organized in a solidary and equitable manner." In de Quental, Causas da Decadęncia dos Povos..., p. 68. Quental had travelled to the United States a few years before, a trip of which not much is known, but one can see he echoes Lincoln's Gettysburg Address of 1863 in these lines.

31 This is contrary to what Onésimo T. Almeida writes in his essay, where he states that Quental does not cite the expulsion of Jews, which is an obvious misreading (see p. 140, footnote 16). See Quental, Causas da Decadęncia dos Povos..., p. 45: “... the expulsion of Jews and the moors impoverishes both nations [Portugal and Spain], paralyses trade and industry, and gives a mortal blow in agriculture ...; the persecution of new Christians allows the capitals to vanish ..." 
and regrets the missed opportunity for civilising belated nations. He writes: "The conquest of belated nations is generally neither fair or unfair. It can be justified or condemned by its results ... The Roman conquests are justified ... because they created a superior civilisation to the one that preceded them. The conquest of India by the British is fair because it civilises. The conquests of India by the Portuguese or of America by the Spanish are unfair because they did not civilise the conquered people." ${ }^{\prime 2}$

José-Augusto França refers to Antero de Quental's diagnosis of decadence as correct ${ }^{33}$ and he recalls the 1870s Generation and their lectures as "superior" and the times in which they were forbidden as "ignominious," ${ }^{34}$ which constitutes a guarded reference to the dictatorial regime (lasting from 1926 to 1974) he himself experienced, along with its nationalism, which promoted isolationism on the international scene.

He clearly inscribes himself as heir of this generation of lucidity in his work about Romanticism in Portugal when he writes: "... the estrangeirados from the Enlightenment were the only Portuguese that could guarantee the viability of the socio-cultural structures of the Portuguese romanticism with their dynamic nationalism and open-mindedness, as was that of Garrett, ..., Antero [de Quental] and Oliveira Martins..." ${ }^{\prime 35}$ For França, they were the exception, as he himself was an exception, the ones who could see the light among the darkness, defending the French Revolution idea of "civilisation," while a generalized mediocrity triumphed. ${ }^{36}$

\section{IMPERIALISM AS CIVILISATION}

One of the "lows" Antero de Quental refers to in his conference is the Portuguese dependence on Great Britain, as a terrible outcome of an ongoing decline. He claims that Portugal had become a British colony while its own colonies were being lost to other countries and the Portuguese influence in China or Japan had disappeared. ${ }^{37}$

32 Quental, Causas da Decadęncia dos Povos..., p. 63. Quental defends the view that civilisation in the colonies implies mixing races and uniting the conquerors and the conquered in the same interests of moral superiority and progress.

33 J.-A. França, O Romantismo em Portugal, vol. 6, Lisbon 1974 [1969], p. 1357.

34 J.-A. França, As Conferęncias do Casino no Parlamento, Lisbon 1973, pp. 9-10.

35 França, O Romantismo em Portugal, vol. 6, p. 1360.

${ }^{36}$ Ibidem, pp. 1354-1355.

${ }^{37}$ Quental, Causas da Decadęncia dos Povos..., pp. 22-23. 
There is a larger context for this lament, of which it is important to emphasise the British support of Portugal in the war against the French invasions of 1807-1810 and later the support in the civil war on the side of the liberals, as well as the "loss" of Brazil as a colony.

The process that had led to Brazil's independence is a direct consequence of the French invasions and of the institutional and trade relations with Britain: with the imminent invasion of the French, the court was transferred in 1807 to Brazil, thanks to the help of the British and Rio de Janeiro was established as the capital of the empire. This escape was made possible after tense negotiations, which would continue in the following years with several adjustments, guaranteeing that Britain would never recognize a non-Portuguese monarch in exchange for trade benefits in America, the promise of future abolition of slave trade and the political, commercial and military support of England in case of conflict. ${ }^{38}$ At the moment of the court's departure, the kingdom was thought lost and shortly after their arrival at Brazil, the state structure was replicated in the colony in line with the one that had existed previously at the metropole, with the result that the empire could be governed from Brazil from then on. Moreover, Brazilian ports were opened for commerce, meaning total economic independence from the metropole, which until then had had exclusive trade rights. Portuguese policies were thus based on the conviction that maintaining the empire was more important than maintaining the metropole, and a new trade map was designed with Brazil at its centre. As the historian Valentim Alexandre concludes, "To give the empire a new centre was to relegate the metropole to the periphery."39

Even after the French defeat in 1814 (with British help), the kingdom would continue to be governed from Brazil until 1821, when King D. João VI was forced to come back to Portugal to deal with a liberal and nationalistic revolt, leaving his son, and future king of independent Brazil, in charge. ${ }^{40}$ The institutional and economic conditions for an autonomous kingdom in Brazil were already created, and independence was declared in 1822, with two monarchies headed by father and son. It is interesting to note that from some political viewpoints, to becoming a colony's colony ${ }^{41}$ was considered worse than facing a colony's independence: it was a real threat, since Brazil's independent

38 See V. Alexandre, "O processo de independência do Brasil," in: História da Expansão Portuguesa, eds. F. Bethencourt and K. Chauduri, vol. 4: Do Brasil para África, Lisboa 1998, pp. $13-17$.

39 Ibidem, p. 17.

${ }^{40}$ Ibidem, p. 26.

${ }^{41}$ M. da Fronteira, Memórias, apud Alexandre, "O processo de independência do Brasil," p. 26. Also p. 36. 
emperor was the direct heir to the Portuguese crown. This is even more so the case because, as one newspaper stated, Brazil had been a country of "savages" until the Portuguese colonization, which was responsible for "civilising" the territory. ${ }^{42}$ To sum up, the trauma consisted firstly of the change of roles: during Portuguese rule, the metropole became subaltern to the colony, for the Portuguese king ruled from Brazil; and secondly, there was the risk of totally and permanently inverting the power relations after independence: the king of Brazil could become king of Portugal by heritage, which would mean to be ruled by a "uncivilised" country.

The nostalgia for an empire that Portugal hadn't been able to hold on to thrived throughout the nineteenth century, sometimes associated with republican ideals and with imperial nationalism that rejected dependence on the British. The responsibility for that dependence was attributed to the monarchy.

With the trauma of the loss of America, attention turned to Africa, justified again by the "civilising mission" and "progress," making the dramatic economic needs of the metropole look like a lesser motive. ${ }^{43} \mathrm{~A}$ series of measures to meet the expansionary ambitions promoted the abolition of slave trade, slavery and forced labour, ultimately giving in to the pressure that Britain had long exerted. Based on humanist values tempered with the belief on the mythical capacities of the Portuguese for civilising, these measures signalled the expectation that divesting of the slave trade would reinforce other areas of investment, and that better economic results would be achieved by a society of free workers. On the other hand, white colonization was promoted, with the purpose of propagating "European values," 44 although effective settlement would only be accomplished after World War I. As for forced labour and servitude, it would be maintained, either openly or more or less covertly, until the outbreak of the colonial war in 1961, with the pretext of its supposedly

42 Campeão Lisbonense, n. 60, 21 May 1822, apud Alexandre, "O processo de independência do Brasil," p. 35.

43 The first version of that project was presented to court in 1836 by the Marquis Sá da Bandeira, but only decades later would it be put to practice. Ibidem, p. 68 .

44 Valentim Alexandre states that there were "ethnocentric" and "integrationist" ideas similar to Tocqueville's and defended by few people, such as Sá da Bandeira or Andrade Corvo: equality between races, defence of the end of slavery and forced labour and the integration of indigenous labour in the economy through wages (while protecting the colonizers' privileges), as well as maintenance of European domination with the goal of civilising otherwise savage peoples. See V. Alexandre, "Nação e Império," in: História da Expansão Portuguesa, eds. F. Bethencourt and K. Chauduri, vol. 4: Do Brasil para África, Lisboa 1998, pp. 94-95, 99-100 and 106-107. 
"civilising function"45. All through the second half of the nineteenth century, both the (scarce) humanist voices against discrimination and those informed by prejudice would invoke the quest for civilisation in the colonial lands, whether they thought it should be gentle and peaceful or violent and imposed.

With the scramble for Africa involving other European countries in the 1870 s and 1880's, including Britain, a new argument emerged fitting in with the expansionist ideas: the argument of scientific knowledge, promoted by the newly created Portuguese Geography Society (1875), which would organize scientific expeditions between Angola and Mozambique again "in the interests of science and civilisation." 46 Soon this argument would be added to mythologised ideas of race and nation, which were also common in other European nationalisms, based on evolutionism and social Darwinism, which would reinforce the belief in the "historical mission" of the Portuguese people, their natural vocation for sea quests and for bringing culture, religion and knowledge to other (naturally inferior) people. ${ }^{47}$ These ideas were propagated by the intellectual elites in newspapers, either echoing or triggering political manoeuvres, governmental changes and legislation. The Berlin Conference in 1884-1885, which determined the demand for "effective occupation" of land to reclaim colonial rights, ${ }^{48}$ and the Brussels Conference in 1889 were full of "humanitarian rhetoric" to justify European countries' sovereignty or influence in Africa as an "ethical and civilisational imperative." ${ }^{49}$ In fact, the need for the definitive abolition of slavery and the slave trade (a sign of civilisation with which everybody agreed, albeit while not practising this abolition) was an argument used in favour of effective land occupation. ${ }^{50}$ Following the in-

45 See M. B. Jerónimo, "The 'Civilisation Guild': Race and Labour in the Third Portuguese Empire, c. 1870-1930," in: Racism and ethnic relations in the Portuguese-speaking world, eds. F. Bethencourt and A. J. Pearce, New York 2012, pp. 173-199.

${ }^{46}$ Decree of 11 March 1877, quoted in Alexandre, "Nação e Império," p. 115.

47 Ibidem, pp. 132-137.

48 The obligation of land occupation referred to coastland and not the interior parts of African territory, contrary to what is usually argued. Ibidem, p. 127.

${ }^{49}$ M. B. Jerónimo, Livros Brancos, Almas Negras. A "missão civilizadora» do colonialismo português 1870-1930, Lisbon 2009, p. 56. Also, Jerónimo, "The 'Civilisation Guild'...," p. 177: "The developmental plans that aimed to transform the role and the function of the overall Portuguese African imperial venture, in which the formulation of effective and efficient policies of native labour had a crucial place, especially after the formal and legal abolition of the slave trade and slavery, were always conditioned by a racialised doctrine of the civilising mission."

50 Jerónimo, "The 'Civilisation Guild'...," p. 180: "Portugal needed to expand territorially in order to civilise trade (to turn commerce into a legitimate taxable enterprise) and with a view to creating the institutional conditions necessary to civilise African populations." 
ternational conferences, a European campaign started questioning Portugal's rights to the colonial land - Portugal was not civilised enough (not European enough) to be civilising others. ${ }^{51}$ Portuguese manoeuvres for land occupation uniting the west and east coast of Africa between Angola and Mozambique would trigger the British Ultimatum (1890), which demanded the immediate withdrawal of Portuguese forces from territories in the sphere of British interests. ${ }^{52}$ This was a traumatizing moment that would add to the two main intellectual currents already referred to: the nationalist one, keen on keeping national pride, and the self-critical one, agreeing with international disdain.

International vigilance would become a source of preoccupation after World War I and with the role assumed by the League of Nations in controlling the international scene after war. However, in spite of reports and incidents, ${ }^{53}$ "the tradition of legalisation for native forced labour continued," ${ }^{54}$ and the Portuguese third empire, as much as the nineteenth and twentieth-century European empires, ${ }^{55}$ was defended by the rhetoric and ideology of the civilising mission, ${ }^{56}$ while the economic enterprise behind it was concealed with the abetment of international organizations. ${ }^{57}$

51 "[Portugal] was being denied the quality of being a European nation with full rights, able to 'civilise' 'belated' people, which struck to the core of an identity built on the idea of the Discoveries as a founding moment in the Portuguese mission in the world," Alexandre, "Nação e Império," p. 126.

${ }^{52}$ Ibidem, p. 129. A Republican revolt followed shortly afterwards as a reaction to the ultimatum in January 1891, associating the policies that led to it with the monarchy.

${ }^{53}$ Such as the Cadbury incident, reporting the conditions of the cocoa workers in S. Tomé (1909), or the Ross Report in 1925, among others. See D. R. Curto, "Preface," in: Jerónimo, Livros Brancos, Almas Negras..., pp. 18-20 and Chapter 5 of the same book, "Novos métodos, velhas conclusões: o Relatório Ross," pp. 211-250.

${ }^{54}$ Jerónimo, "The 'Civilisation Guild'...," p. 199.

${ }^{55}$ For the European empire rhetoric see F. Cooper, "States, Empires, and Political Imagination," in: Colonialism in Question: Theory, Knowledge, History, Berkeley 2005, pp. 153-203.

${ }^{56}$ I follow here Miguel B. Jerónimo's analysis, who emphasizes the economic motivations of the empire, diverging with Valentim Alexandre, who concludes that the Portuguese colonial project in the nineteenth century was firstly strategic (in relation to Madrid's power) and ideological (the country's self-image constructed by the elites that establish the mythical historical civilising mission of Portugal since the fifteenth-century), and that the economic motivations were secondary, although they would eventually prevail in the early twentieth century. V. Alexandre, "O império português (1825-1890): ideologia e economia," Análise Social 2004, 39(169), pp. 959-979.

57 Curto, "Preface," p. 40. 
The narrative of civilisation had to do with inferiority complexes which determined political stances, ultimately leading to the end of monarchy in Portugal in 1910. Quental's lament of the Portuguese dependence on Britain was the expression of deeper feelings: the mourning for the loss of Brazil and mourning for not being as civilised as the British. Quental and Sérgio, and others like them, suffered the "estrangeirado" effect: they too considered Portugal insufficiently civilised to be able to civilise others.

What is at stake here is what Fredrick Jameson refers to in his 1988 essay "Modernism and Imperialism": "during this period the word 'imperialism' designates, not the relationship of metropolis to colony, but rather the rivalry of the various imperial and metropolitan nation-states among themselves." ${ }^{\prime 5}$ That meant to "repress the axis of otherness," raising "issues of colonial reality only incidentally" and making the colonial other invisible. ${ }^{59}$ Therefore, barbarism and civilisation were terms to judge nations within the imperialist rhetoric of rivalry between empires. In Portugal, both the estrangeirados and the nationalists wanted to play alongside the most powerful nations. Since Portugal experienced economic dependence and subordination towards one of them, and adding the recent events in Brazil, its place is an ambiguous one for the mentioned Portuguese intellectuals, who wanted the country to be an empire and at the same time were afraid of being treated like a colony. Jameson's thesis is that western imperialism since the 1880's Scramble for Africa by western powers (which means imperialism associated with capitalism, progress, economic growth and technological revolution) is constitutive of modernism and can be found in modernist literature, not in an explicit way but structurally, as "formal symptoms" ${ }^{60}$, and therefore the modernism-as-for-

${ }^{58}$ In T. Eagleton, F. Jameson, E. Said, Nationalism, Colonialism and Literature, Minneapolis, London 1990, p. 47.

59 Ibidem, p. 51. The full quotation is: "From 1884 to World War I, the relationship of domination between First and Third World was masked and displaced by an overriding (and perhaps ideological) consciousness of imperialism as being essentially a relationship between First World powers or the holders of Empire, and this consciousness tended to repress the more basic axis of otherness, and to raise issues of colonial reality only incidentally."

${ }^{60}$ Ibidem, p. 64. Jameson is analyzing how modernist literature is written from the point of view of the metropolis, and even if the colonies or the colonized are part of the narrative, they are outside the daily life of the First World countries, which are literature's "raw material": the empire is represented by the unknown and "the inability to grasp the way the system [colonial power and colonies] functions as a whole" (p. 51) prevails; therefore, an undetermined and exterior infinity is often present in the modernist narrative. It is not a matter to discuss here, but Jameson tries to make a point regarding the particularity of Irish modernism (James Joyce, in particular), a modernism he thinks has "slyly turned the 
malism trope is never really apolitical. I may add that if art history writing developed within a modernist frame, then imperialism is also structurally constitutive of it.

\section{JOSÉ-AUGUSTO FRANÇA'S ART HISTORY — ART AS CIVILISATION}

Working as an art critic, editor, curator and art historian, José-Augusto França developed a narrative based on the sociology of art learned with Pierre Francastel (1900-1970), with whom he studied in Paris. This narrative elected Paris as an artistic and cultural role model and a permanent delay of Portuguese art was diagnosed through comparisons with that model. França wrote with an empiricist methodology compiling facts and vigorously defending an anti-theory position, ${ }^{61}$ which was celebrated both by himself and by later art historians as "evidence." ${ }^{\prime 2}$ This came in line with the positivist approach of the early twentieth-century art historians, in which fact accumulation gave scientific credibility and the illusion of neutrality to history-making. It was also in line with the estrangeirado symptom that elected foreign models with which to compare Portuguese art, finding it always below international expectations. There are also more complex connections to be made with the embedded narrative of civilisation previously commented, which will be made later on.

França begun by writing novels, but he soon became an art and cinema critic as well as gallerist, and he also tried painting. His first novel takes place in Angola, where he lived after his father died, from 1941 to 1945, and tried to take care of the family business related to the coffee trade. He came back because, as he said sixty years later, he could not adapt to seeing the misery caused by "vile colonialism." ${ }^{63}$ Until 1962, when he presented his thesis in history at the Sorbonne in Paris (where he began studying in 1959) about the reconstruction of Lisbon following the 1755 earthquake, he was mainly an art

imperial relationship inside out" (p. 64) due to its decentered and subjugated condition, but close enough to the metropole to share with it the modernist quest.

${ }^{61}$ J.-A. França, "Sobre História (Sociológica) da Arte," in: (In)definições de Cultura, Lisbon 1997 [1979/81], p. 109.

${ }^{62} \mathrm{He}$ also argued that no one but the authors of the epoch being studied should be cited, in order to guarantee objectivity. J.-A. França, O Romantismo em Portugal, Lisbon 1974 [1969], vol. 1, pp. 17-18. The intromission of theory was a fault, for it belonged to the dominion of "ideas" and "abstraction" and not the dominion of facts. França, "Sobre História (Sociológica) da Arte," p. 109.

${ }^{63}$ França, interview by Saraiva. 
critic and curator. He promoted the first surrealist exhibitions in Lisbon in 1949, where he participated as an artist, ${ }^{64}$ and afterwards in 1952, assuming at that time the role of curator. In that same year, he opened his own gallery, Galeria de Março, and although it would only be active for two years, more than thirty exhibitions were organized, showing modernist artists, surrealism and shortly after, abstract art. ${ }^{65}$

When França presented his specialization thesis on the sociology of art, written under the supervision of Pierre Francastel, in 1963 at the École des Hautes Études in Paris, titled A Arte e a Sociedade Portuguesa do Século $X X$ [Portuguese Art and Society in the Twentieth-Century], he proposed an imaginary graphic to explain twentieth-century Portuguese art. The graphic had two high points: avant-garde and futurism in 1915-1917, followed by an accentuated depression that lasted until surrealism and abstractionism in 1945-1947 and after. ${ }^{66}$ The depression corresponded to belatedness, which França explained as a consequence of a non-transmission of knowledge between different generations of artists. The graphic, made as an art historian, confirmed his own choices as an art critic in previous years, tracing an evolution from surrealism to abstractionism that had really no basis in reality. In fact, the first abstractionist paintings were made before the first surrealist experiments, but França only included them in the narrative after they were exhibited in his own gallery in 1953, therefore maintaining the linear progressive story of Portuguese art. ${ }^{67}$

His work on Romanticism in Portugal, a thorough investigation with no parallel in Portuguese art historiography, was presented as a doctoral thesis to the Sorbonne in 1969, and would again use an imaginary graphic to conclude that although some positive points emerged, the general balance was very negative for nineteenth-century Portuguese art. ${ }^{68}$ Belatedness is also a key issue when he considers that the Portuguese nineteenth century ended only in 1910 in another major two-volume edition, A Arte em Portugal no Século XIX

${ }^{64}$ The surrealists divided immediately into two groups, one called Grupo Surrealista de Lisboa [Lisbon's Surrealist Group] and the other called simply Os Surrealistas [The Surrealists]. França was part of the first group and elected the older artist António Pedro as a tutorial figure.

65 J.-A. França, A Arte em Portugal no Século XX, Lisbon 1991 [1974], pp. 480-481.

66 J.-A. França, A Arte e a Sociedade Portuguesa no Século XX, Lisbon: 1972 [1963].

${ }^{67}$ The first abstraction exhibitions were made by Fernando Lanhas, Nadir Afonso and others in Porto, in 1943-44. A. Portela, Salazarismo e Artes Plásticas, Biblioteca Breve, 1982. See also the book written in the dual role of critic and art historian, J.-A. França, Pintura Abstracta Portuguesa em 1960, Lisbon 1960.

${ }^{68}$ França, O Romantismo em Portugal, vol. 6, pp. 1355-1359. 
[Art in Portugal in the Nineteenth-century]. ${ }^{69}$ Romanticism is used as a given concept: ${ }^{70}$ it was the art of nineteenth-century Europe, and Portugal, a European country, generally failed to accomplish it.

Both O Romantismo em Portugal and another book, Os Anos Vinte em Portugal [The 1920s in Portugal] published in 1992, have the same subtitle, "Studies on Socio-Cultural Facts." Almost all of his introductions to his books refer to his art history work as such, or as studies on the "facts of civilisation." ${ }^{\prime 11}$ This designation is taken directly from Pierre Francastel's Sociologie des Objets de Civilisation, which is the basis of the French author's wellknown book Art and Technology in the Nineteenth and Twentieth Centuries, in which he states that art is as much an object of civilisation as technology and that both are interrelated. ${ }^{72}$ França writes, following Francastel, that "a cultural fact reflects social values and at the same time, proposes values to society."73 In later texts he allows a further designation, "artistic fact," always referring to its double function: reflecting and proposing. ${ }^{74}$ For França, the proponent function is what makes art a civilising factor. Although França's approach was inscribed in the field of the sociology of art, he maintained that the "artistic fact" is a totality, and it has full autonomy. It is the role of the expert, the art historian (and critic), to bring that artistic fact intact in its unity and to identify how it functions and how it acts in society: "An object of civilisation lives its conjunctures: the sociology of objects of civilisation reveals them. ${ }^{175}$

França's education with Francastel confirmed and fuelled the narrative of belatedness based on the contrast between civilisation and "primitive," or "underdeveloped," which was well established in the Portuguese intellectual tradition. As seen in Antero de Quental, the question the intellectuals wor-

69 And started earlier, 1780 (which corresponds to the reconstruction of Lisbon after the earthquake). See J.-A. França, A Arte em Portugal no Século XIX, Lisbon 1990 [1967], p. 14.

${ }^{70}$ The same occurs in other works with concepts like modernity and enlightenment. Enlightenment is identified in Portugal as taking place during the rule of the Marquis of Pombal and corresponding to an empirical absorption of ideas that had been "in the air for a long time." J.-A. França, Lisboa Pombalina e o Iluminismo, Lisbon 1966 [1965], p. 305.

${ }^{71}$ Namely in the referred books and, for instance in França, A Arte em Portugal no Século XX, p. 8.

72 P. Francastel, Art and Technology in the Nineteenth and Twentieth Centuries, MIT Press, 2000 [1956], p. 151.

${ }^{73}$ França, O Romantismo em Portugal, p. 13.

74 J.-A. França, "Verdade Prática e Verdades Práticas" (1963) and "Sobre História (Sociológica) da Arte" (1979/81), in: idem, (In)definições de Cultura, p. 144 and 116.

75 J.-A. França, "O 'facto artístico' na sociologia da arte” (1987), ibidem, p. 105. 
ried about was the inability to be civilised and also the authoritarian regimes that had contributed to the decadence and progressive loss of civilising (European) qualities. Adopting this position meant that França was fighting and assuming an oppositional position to the Portuguese fascist regime he was witnessing, just as Quental had been against absolutism, and as António Sérgio, França's contemporary, was against the dictatorship of Salazar. However, he maintained the order of discourse $e^{76}$ that prevailed and that assumed a privileged historical position for Europe, synonymous to civilisation. Furthermore, European art was seen as synonymous with civilisation, a common idea widely shared both in popular opinion and in art history practice - one can recall Kenneth Clark's BBC show that screened in 1969 precisely under the title 'Civilisation'.

What did it mean to be civilised? It meant being European, it meant not to be left on the periphery. ${ }^{77}$ And if art had full autonomy and yet a civilising function, it had failed to include Portugal among the civilised. The conception of art as a civilising factor and as an autonomous totality allows one to blame art, independently of external facts, for not civilising, that is, art was responsible for its own belatedness (and for society's belatedness) - it had an inherent incapacity to affirm itself within European parameters.

It is in this context that França's defence of abstraction, joining his voice to the mainstream narrative as so many other artists and art historians, should be understood. In France, after World War II, and in rivalry with the USA, it was also abstract art that was elevated to the position of absolute modern art. A three-volume publication in 1973 claimed French ownership of abstract art, arguing that the weight of the French capital in Western art gave it special status and affirming that abstraction dominated in Paris since $1945 .{ }^{78}$ It is this French side that França chooses, adopting the designation "abstraccion lyrique"79 to promote abstract Portuguese artists. That designa-

${ }^{76}$ I use Michel Foucault's term for the invisible set of rules that determine one's choice of words, of thoughts, of actions and that one is seldom aware of. See M. Foucault, The Order of Things, New York 1970 [1966].

77 Foteini Vlachou has analysed the concept of periphery extensively in terms of a temporal unit rather than spatial, and how it implicates the judgment of backwardness for those countries which are not considered the centre, in "Why Spatial? Time and the periphery," Visual Resources 2016, 32(1-2), pp. 9-24 (DOI: 10.1080/01973762.2016.1132500), included The Disappointed Writer. Selected Essays, Lisboa 2019.

78 M. Seuphor, M. Ragon, L'Art abstrait, 1939-1970, Paris 1973.

79 "Lyric abstraction" was used in 1947 by Jean Marchand and Georges Mathieu for the exhibition in the Gallery of Luxembourg in Paris L'Imaginaire. See D. Vallier, A Arte Abstracta, Lisbon 1980, p. 279. 
tion was coined to concur with North American "abstract expressionism," and to claim to be its predecessor. By promoting abstractionism in Portugal, França finally aligned Portugal with European civilisation. In other words, the regular diagnosis of belatedness regarding a peripheral European country is aligned with the master narrative that hierarchizes continents and countries in power relations which are both the producers and the products of the master narrative.

This sedimented idea prevailed after the Carnation Revolution of 1974, in fact, José-Augusto França produces a vast amount of work after the revolution and in the meantime he became the director of the most important art magazine, published by Fundação Calouste Gulbenkian, Colóquio Artes (1971-1996). It is also after the revolution that his art history became institutionalized, with the creation of the Art History Department at Universidade Nova de Lisboa in 1974. In general, art history books written by younger art historians dedicated to nineteenth and twentieth centuries (and even before), divided, as França did, the chronology into decades, artists in generations ${ }^{80}$, which succeed one another in linear progression and always with a fatal and unavoidable belatedness, except for celebrated punctual cases of success. ${ }^{81}$ Although some new work emerged, França's methodology nevertheless remained a vital reference to art historians, and his chronologies, historical concepts and extensive inventories of facts were never entirely questioned and were used as sources for later art historical writing. As Paulo Varela Gomes wrote in 2009: "... forty years after 1967 we have evolved little in matters of knowledge and problematization of the themes to which J.-A. França dedicated his first volume on nineteenth-century art in Portugal. Everything written since then is nothing more than the substitution of some pieces of França's puzzle and the invention of one or two new pieces." ${ }^{\prime 2}$

Nevertheless, other forms of writing about Portuguese art history have been tested, such as Paulo Varela Gomes' work, who tried not to use catego-

${ }^{80}$ For the concept of generation in França's A Arte em Portugal no Século XX (19111961) see A. R. Salgueiro, “A Arte em Portugal no século XX (1911-1961).” José-Augusto França e a perspectiva Sociológica, Lisbon 2012, p. 62, 63 e 82 e ss.

${ }^{81}$ See R. M. Gonçalves, História da Arte em Portugal, vol. 13: Pioneiros da Modernidade, Lisbon 1988; B.P. de Almeida, Pintura Portuguesa do Século XX, Porto 1994 (this book had an extended version published in 2017: Arte Portuguesa no Século XX, Porto); P. Pereira (ed.), História da Arte Portuguesa, vol. 3, Lisbon 1995; D. Rodrigues (ed.), Arte Portuguesa. Da Pré-História ao Século XX, vol. 18: O modernismo I (J. Pinharanda) and vol. 19: O modernismo II (B. P. de Almeida), Vila Nova de Gaia 2009.

${ }^{82}$ P. V. Gomes, Arte Portuguesa, ed. D. Rodrigues, vol. 14: Expressões do Neo-Clássico, Vila Nova de Gaia 2009, pp. 18-19. 
ries and concepts from the master narrative which he found inadequate to Portuguese subjects, or Foteini Vlachou who paid meticulous attention to the social, economic and political conditions for art production in Portugal in the eighteenth- and nineteenth centuries, for instance noticing that the investment in decorative arts and crafts was much more significant than in academy education, therefore understanding the institutional and political reasons for not investing in better artistic education in painting or sculpture. ${ }^{83}$ This was a situation, I might add, that caused several avant-garde and modernist artists from the early twentieth-century to be self-taught. There are also several academic works, articles and theses that contribute to another kind of art history-making, but dominant art history is still Eurocentric.

\section{CIVILISATION AND BARBARISM}

It is significant to find Francastel writing about the superiority of the European (white) race: "I am led to believe that the nonstop progression of the white man - and of him alone - over thousands of years explains his de facto ascendancy over the planet, a privilege he has obtained by virtue not of racial predestination but of historical and societal gains. Only Western societies have proved adaptable ... Man's entire history teaches that the only great societies are those in which adaptation occurs not by empirical accommodation to exterior conditions, but by well-thought-out domination of materials. The greatness of the European race resides in its once again having assumed power, in the past two centuries, ... over all collective values, of which art is undoubtedly one means of expressing ..." ${ }^{84}$

Francastel justifies his Eurocentric view by arguing that Europe is the home of outstanding technical and artistic capacities that made the continent more adaptable, therefore associating those capacities with the ability to construct a superior civilisation, or, to use evolutionist terms, a civilisation that wins its place by shadowing the others. As Samir Amin wrote, Eurocentrism is based on prejudice and on the idea of Europe as a superior universal model, believed to be imposed by the "force of circumstances" and natural evolution. That is based on the attribution of "more or less permanent characteristics to

83 Gomes, Expressões do Neo-Clássico; F. Vlachou, The Disappointed Writer. Selected Essays, Lisboa 2019.

${ }^{84}$ Francastel, Art and Technology..., pp. 134-135. In a rather harsh introduction to the MIT Press edition of Francastel's Art and Technology, Yve-Alain Bois writes: "the seriousness of Francastel's book is badly tarnished by his inveterate chauvinism," p. 9; adding that he says, "in short, that Europe invented it all," p. 10. 
a people or group of peoples," which are "drawn from totalizing conclusions from single details," considering them valid to "justify their condition and evolution." ${ }^{85}$ This has been the common ground for the modern construction of European identity - especially after the Enlightenment - and for constructing identities inside Europe, electing models which other countries can get close to or fail to emulate, being "less European" than others. This construction is ideological and has sustained economic and political power, in which art and culture have played its part.

Art history has contributed to this Eurocentric ideology: as is well known, it was born as a scientific discipline from a Eurocentric position that mythified Antiquity (Greece) as the birth of culture. Jacob Burckhardt's The Civilisation of the Renaissance in Italy (1860), with its thorough examination of every aspect of culture, embedding art in its cultural, political, economic and religious context, helped to establish the equivalence between art and civilisation, considering them mutually interdependent..$^{86}$ The ultimate example of civilisation, and therefore of art, was Renaissance Italy. For Francastel and his student José-Augusto França, it would be modern France (or, more accurately, Paris). In short, the historiography of art takes European superiority for granted from the Renaissance on.

In his famous book Provincializing Europe. Post-colonial thought and historical difference, Dipesh Chakrabarty mentioned how the imperial narrative, produced either by and under colonial rule, either by Indian nationalists had "the tendency to read Indian history in terms of a lack, an absence, or an incompleteness that translates into 'inadequacy'" and how that narrative was the "cornerstone of imperial ideology." 87 That means that the Indians, as subjects of history, always had a subaltern position and were always (self-)seen as belated regarding (European) civilisation. To be modern was, as Chakrabarty puts it, to be European, a fictionalized Europe for sure, a mirage that nevertheless maintained the power relations between countries, and that determined the pattern to look up to, but that could never really be reached. ${ }^{88}$ Indian his-

${ }^{85}$ S. Amin, "The construction of eurocentric culture," in: Eurocentrism. Modernity, Religion, and Democracy. A Critique of Eurocentrism and Culturalism, New York 2009 [1988] (ebook edition).

${ }^{86}$ Understanding art as always interdependent with social, political, economic, religious or cultural facts was a critical and innovative approach that led to cultural history.

87 D. Chakrabarty, "Historicism as a transition narrative," in: idem, Provincializing Europe. Postcolonial thought and historical difference, Princeton University Press, 2008 [2000] (ebook edition).

${ }^{88}$ Edward Said's Orientalism was, of course, a pivotal work that analysed how knowledge production about Orient in the West was both a reflection and an instrument for main- 
tory became a variant of the European master narrative, and Europe was thus sovereign in that narrative. ${ }^{89}$

When Francastel writes about Western superiority, he is expressing the imperialist way of thinking that had been an important factor in consolidating the discipline of art history. França's art history, purporting to be a master narrative and part of the Western master narrative, adopted a subaltern position which, when exceeded, could be celebrated, for it meant that marginal Europe was catching up with the centre, with civilised Europe. França's belatedness also plays a part in identifying the old necessary to the process of writing modern(ist) history. He needs something old to contrast with novelty (and progress), newness being measured according to the Parisian model. It is also an intellectual task that includes him in the national tradition of the self-critique promoted by the estrangeirados (and that makes him look at the past historians in accordance with his own historiographical stance) and the way he thought to be contributing to the overcoming of belatedness by acknowledging it.

Nevertheless, the subaltern position he assumes for Portuguese art (and many after him) and the desire to overcome it only reinforces eurocentrism and the Eurocentric master narrative. It contributes to the prevailing imperial European way of thinking that is based on rivalry and hierarchies between winners and losers. Although Chakrabarty's analysis is useful to understand established hierarchies that determined who gets to be modern and who doesn't and that establish the requisites for reaching modernity, it cannot simply be taken as a parallel to the situation of Portuguese art history. Indeed,

taining a sovereign/subaltern power relation between both. "Orientalism is a western style for dominating, restructuring, and having authority over the Orient. [It is a discourse] by which European culture was able to manage-and even produce-the Orient politically, sociologically, militarily, ideologically, scientifically, and imaginatively during the post-Enlightenment period." E. W. Said, "Introduction, I," in: idem, Orientalism, New York 2004 [1978] (ebook edition). He adds that creating the "Orient" was a way for the (European) West to define itself and its sovereign position in relation to an Oriental backwardness and in such a way that "the European idea of the Orient" was the only legitimate idea of the Orient: "... political imperialism governs an entire field of study, imagination, and scholarly institutions-in such a way as to make its avoidance an intellectual and historical impossibility." In "Introduction, III," ibidem.

89 See D. Chakrabarty, "Postcoloniality and the Artifice of History," in: idem, Provincializing Europe... Dipesh Chakrabarty self-criticises the post-colonial project of Subaltern Studies, of which he was one of the founders, which also assumed this narrative, and proposes reading the idea of a "lack" differently, substituting it in the master narrative for "plenitude" and "creativity," allowing for multiple narratives about multiple experiences of modernity. See "To read lack otherwise," ibidem. (ebook edition). 
the Portuguese stance in the work of the authors, historians, writers and philosophers cited so far was based on the faith on Portuguese European roots and on the imperative to avoid being treated or perceived as an Empire does its colonies. The ambition was to be perceived as a European nation, with its privileges in the narrative of the modern.

If one considers that "knowledge is produced under organized political circumstances $^{\prime \prime 90}$, then one must see that the Portuguese art history canon was shaped by the international European scene and by the Portuguese ambition to be a part of its constructed image of modernity. One has to take into consideration how the canon was modelled to that image of modernity, which narrows its definition to an experience only valued if it is similar to the "centres of civilisation." To be able to determine that similarity or the failure to achieve it and the consequent diagnosis of ultimately not being "civilised" enough was a role that gave European status to the art historian. The art historian's judgement of civilisation or barbarism would put him, if not his country, in the centre.

Is it possible to have a non-Eurocentric European art history? Chakrabarty has remarked that we all make European history, even with non-European archives - there is no escape from that. Yet he embraces the project of "provincializing 'Europe,' the Europe that modern imperialism and (third-world) nationalism have, by their collaborative venture and violence, made universal." ${ }^{\prime 11}$ Boaventura de Sousa Santos has proposed the exercise of abyssal thinking to reach the realities outside the Eurocentric production of knowledge: "What cannot be said, or said dearly, in one language or culture may be said, and said dearly, in another language or culture. Acknowledging other kinds of knowledge and other partners in conversation for other kinds of conversation opens the field for infinite discursive and nondiscursive exchanges with unfathomable codifications and horizontalities." 92

A resonance to these words can be found in Piotr Piotrowski's horizontal art history. Piotrowski underlines the importance of the place from where the historian writes: "Due to the ideology of the universalism of modern art, the historian of the centre, often quite unconsciously, tends to ignore the significance of place, thus becoming an instrument of colonization"93 and, I will

90 E. W. Said, "Introduction, III" in: idem, Orientalism.

91 E. W. Said, "History and difference in Indian modernity," ibidem.

92 B. Sousa Santos, "Minifesto for Intellectual-Activists," in: idem, Epistemologies of the South: Justice against Epistemicide, Routledge, 2014 (ebook edition).

93 P. Piotrowski, "Toward a Horizontal Art History of the European Avant-Garde," in: Europa! Europa? The Avant-Garde, Modernism and the Fate of a Continent, ed. S. Bru et al., New York 2009, p. 55. 
add, the historian of the periphery who puts places the objects of its research in a belatedness relation towards the centre also becomes that sort of instrument.

Walter Benjamin famously wrote that "there is no document of culture which is not at the same time a document of barbarism." ${ }^{\prime \prime 4}$ Civilisation and barbarism are terms that have been historically opposed, and they have played a fundamental part in the modernist narration of modernity. The challenge is not to see them as opposites, for they are interconnected and interchangeable constructed concepts. Acknowledging that is perhaps a task suited for the peripheral art history of today, which has to come to terms with the belatedness trope and its Eurocentric implications, including its imperialist trail.

\section{BIBLIOGRAPHY}

Alexandre V., "O processo de independência do Brasil" and "Nação e Império," in: História da Expansão Portuguesa, eds. F. Bethencourt and K. Chauduri, vol. 4: Do Brasil para África, Lisboa 1998

Alexandre V., "O império português (1825-1890): ideologia e economia," Análise Social 2004, 39(169), pp. 959-979

Almeida B. P. de, Pintura Portuguesa do Século XX, Porto 1994

Almeida O. T., "Antero de Quental on the Causes of the Decline of the Iberian Peoples: A Revisitation," Mediterranean Studies 1989, 1

Amin S., Eurocentrism. Modernity, Religion, and Democracy. A Critique of Eurocentrism and Culturalism, New York 2009 [1988]

Beiser F., The German Historicist Tradition, Oxford University Press, 2011

Benjamin W., "On the Concept of History" [1940], in: idem, Selected Writings, eds. H. Eiland, M. W. Jennings, vol. 4, Harvard University Press, 2003

Carneiro A., A. Simões, M. P. Diogo, "Enlightenment Science in Portugal: The Estrangeirados and Their Communication Networks," Social Studies of Science $2000,30(4)$

Chakrabarty D., Provincializing Europe. Post-colonial thought and historical difference, Princeton University Press, 2008 [2000]

Cooper F., "States, Empires, and Political Imagination," in: idem, Colonialism in Question: Theory, Knowledge, History, Berkeley 2005

Curto D. R., "Preface," in: M. B. Jerónimo, Livros Brancos, Almas Negras. A «missão civilizadora» do colonialismo português 1870-1930, Lisbon 2009

Eagleton T., F. Jameson, E. Said, Nationalism, Colonialism and Literature, Minneapolis/London 1990

Foucault M., The Order of Things, New York 1970 [1966]

94 W. Benjamin, "On the Concept of History" [1940], in: idem, Selected Writings, eds. H. Eiland, M. W. Jennings, vol. 4, Harvard University Press, 2003, p. 342. 
França J.-A., Pintura Abstracta Portuguesa em 1960, Lisbon 1960

França J.-A., Lisboa Pombalina e o Iluminismo, Lisbon 1966 [1965]

França J.-A., A Arte e a Sociedade Portuguesa no Século XX, Lisbon 1972 [1963]

França J.-A., As Conferęncias do Casino no Parlamento, Lisbon 1973

França J.-A., O Romantismo em Portugal, 6 vol., Lisbon 1974 [1969]

França J.-A., A Arte em Portugal no Século XIX, Lisbon 1990 [1967]

França J.-A., A Arte em Portugal no Século XX, Lisbon 1991 [1974]

França J.-A., "Verdade Prática e Verdades Práticas" [1963]; "Sobre História (Sociológi-

ca) da Arte" [1979/81] and "O 'facto artístico' na sociologia da arte" [1987], in: (In) definições de Cultura, Lisbon 1997

França J.-A. interviewed by J. C. Saraiva, Sol, Lisbon, May 2016

Francastel P., Art and Technology in the Nineteenth and Twentieth Centuries, New York 2000 [1956]

Gomes P.V., "Cyrillo Volkmar Machado e a História da Arte em Portugal na transição do século XVIII para o século XIX," in: idem, A Cultura Arquitectónica e Artística em Portugal no século XVIII, Lisbon 1988

Gonçalves A. M., "Historiografia de Arte em Portugal," Boletim da Biblioteca da Universidade de Coimbra 1960, 25

Gonçalves R. M., História da Arte em Portugal, vol. 13: Pioneiros da Modernidade, Lisbon 1988

Jerónimo M. B., Livros Brancos, Almas Negras. A "missão civilizadora» do colonialismo português 1870-1930, Lisbon 2009

Jerónimo M. B., "The 'Civilisation Guild': Race and Labour in the Third Portuguese Empire, c. 1870-1930," in: Racism and ethnic relations in the Portuguese-speaking world, eds. F. Bethencourt and A. J. Pearce, New York 2012

Lourenço E., "Os Círculos dos Delaunay ou o Estatuto da nossa Pintura," in: idem, O Espelho Imaginário. Pintura, Anti-Pintura, Não-Pintura, Lisbon 1996 [1971]

Osborne P., "Historicism as bad modernity," in: idem, The Politics of Time: Modernity and the Avant-Garde, London 1995

Pereira P. (ed.), História da Arte Portuguesa, vol. 3, Lisbon 1995

Piotrowski P., "Toward a Horizontal Art History of the European Avant-Garde," in: Europa! Europa? The Avant-Garde, Modernism and the Fate of a Continent, ed. S. Bru et al., New York 2009

Portela A., Salazarismo e Artes Plásticas, Biblioteca Breve, 1982

Quental A. de, Causas da Decadęncia dos Povos Peninsulares [1871], Lisbon [no date]

Rodrigues D. (ed.), Arte Portuguesa. Da Pré-História ao Século XX, vol. 14: Expressões do Neo-Clássico (P. V. Gomes); vol. 18: O modernismo I (J. Pinharanda); vol. 19: O modernismo II (B. P. de Almeida), Vila Nova de Gaia 2009

Rosas F., Salazar e os fascismos, Lisbon 2019

Rosmaninho N., "Estratégia e Metodologia na Historiografia Artística Portuguesa (1846-1935)," Revista da Universidade de Aveiro. Letras 1997, 14

Said E., Orientalism, New York 2004 [1978]

Salgueiro A. R., “A Arte em Portugal no século XX (1911-1961).” José-Augusto França e a perspectiva Sociológica, Lisbon 2012 
Sérgio A., "O reino cadaveroso ou o problema da cultura em Portugal," in: idem, Ensaios II, Lisbon 1972 (2 $2^{\text {nd }}$ edition)

Seuphor M., M. Ragon, L'Art abstrait, 1939-1970, Paris 1973

Sousa Santos B. de, Epistemologies of the South: Justice against Epistemice, New York 2014

Vlachou F., "Why Spatial? Time and the periphery," Visual Resources 2016, 32(1-2), pp. 9-24

Vlachou F., The Disappointed Writer. Selected Essays, Lisbon 2019

Mariana Pinto dos Santos

Universidade Nova de Lisboa

ON BELATEDNESS.

THE SHAPING OF PORTUGUESE ART HISTORY IN MODERN TIMES

Summary

Portuguese art history experienced remarkable development after World War II, especially with the work of José-Augusto França, who was responsible for establishing a historiographic canon for nineteenth- and twentieth-century Portuguese art that still endures. José-Augusto França developed a narrative that held Paris up as an artistic and cultural role model in relation to which he diagnosed a permanent delay in Portuguese art. This essay analyses França's idea of belatedness in the context of Portuguese art historiography and political history and how it is part of a genealogy of intellectual thought produced in an imperial context, revisiting previous art historians and important authors, such as Antero de Quental and António Sérgio. Moreover, it aims to address how the concept of belatedness was associated with the idea of "civilisation" and the idea of "art as civilisation." Belatedness also has implications in the constraints and specificities of writing a master narrative in a peripheral country - a need particularly felt in the second half of the twentieth century, to mark a political standpoint against the dictatorship that ruled from 1926 to 1974. Part of the reaction to fascism expressed the desire to follow other nations' democratic example, but the self-deprecating judgements on Portuguese art were frequently associated with the identification of essentialist motifs - the "nature" of the Portuguese people, their way of thinking, of living, their lack of capacities or skills - and of a self-image of being "primitive" in comparison with other European countries that has antecedents going back to the eighteenth century. I will address the nostalgia for the empire and the prevailing notion of belatedness throughout the twentieth century regarding unsolved issues with that nostalgia.

Keywords:

belatedness, historiography, modernism, civilisation, eurocentrism, periphery 